\title{
Exchange of domains of glutamate dehydrogenase from the hyperthermophilic archaeon Pyrococcus furiosus and the mesophilic bacterium Clostridium difficile: effects on catalysis, thermoactivity and stability
}

\author{
Joyce H.G.Lebbink ${ }^{1}$, Rik I.L.Eggen ${ }^{1,2}$, \\ Ans C.M.Geerling1, Valerio Consalvi ${ }^{3}$, \\ Roberta Chiaraluce ${ }^{3}$, Roberto Scandurra ${ }^{3}$ and \\ Willem M.de Vos ${ }^{1,4}$

\begin{abstract}
'Department of Microbiology, Wageningen Agricultural University, and 'Dipartimento di Scienze Biochimiche 'A Rossi Fanelli', Universita 'La Sapienzal, Piazzale Aldo Moro 5, 1-00185, Roma, Italy

${ }^{2}$ Present address: Swiss Federal Institute for Environmental Science and Technology (EAWAG), Ueberlandstrasse 133, CH-8600) Duebendorf, Switzerland
\end{abstract} \\ Hesselink van Suchtelenweg 4, NL-6703 CT Wageningen, The Netherlands \\ tro whom correspondence should be addressed
}

The glutamate dehydrogenase gene from the hyperthermophilic archaeon Pyrococcus furiosus has been functionally expressed in Escherichia coli under the control of the $\lambda$ $P_{L}$ promoter. The Pffuriosus glutamate dehydrogenase amounted to $20 \%$ of the total E.coli cell protein, and the vast majority consisted of hexamers. Following activation by heat treatment, an enzyme could be purified from E.coli that was indistinguishable from the glutamate dehydrogenase purified from P.furiosus. Hybrid genes, that consisted of the coding regions for the homologous glutamate dehydrogenases from P.furiosus and the mesophilic bacterium Clostridium difficile, were constructed and successfully expressed in E.coli. One of the resulting hybrid proteins, containing the glutamate binding domain of the C.difficile enzyme and the cofactor binding domain of the P.furiosus enzyme, did not show a detectable activity. In contrast, the complementary hybrid containing the P.furiosus glutamate and the C.difficile cofactor binding domain was a catalytically active hexamer that showed a reduced substrate affinity but maintained efficient cofactor binding with the specificity found in the Clostridium symbiosum enzyme. Compared with the C.difficile glutamate dehydrogenase, the archaeal-bacterial hybrid is slightly more thermoactive, less thermostable but much more stable towards guanidinium chloride-induced inactivation and denaturation.

Keywords: glutamate dehydrogenase/heterologous expression/ hybrid enzymes/Pyrococcus furiosus/thermostability

\section{Introduction}

The discovery of microbes that have the capacity to grow optimally at or around the boiling temperature of water (Stetter et al., 1990) has greatly stimulated the analysis of the molecular mechanisms of adaptation of these hyperthermophilic organisms to their extreme environment. Considerable attention has been focused on protein thermostability that is generally accompanied by a stability towards chemical denaturants and proteolysis (Fontana, 1991). Theoretical considerations in combination with protein sequence comparisons have indicated that protein thermostability is a consequence of small but multiple changes distributed all over the protein (Jaenicke,
1991). Site-directed and random mutagenesis studies have been used to investigate the contribution of specific interactions to protein stability and have confirmed that only a few residues play a critical role in achieving thermal and chemical stability (Goldenberg, 1992). The recent elucidation of the 3-D structures of several proteins from thermophilic microbes and their comparison with proteins from mesophilic sources have advanced the understanding of the thermal stability of proteins. Although various different mechanisms have been identified by which the thermal stabilization of proteins may occur, an analysis of the structures of rubredoxin and aldehyde ferredoxin oxidoreductase from the hyperthermophilic Pyrococcus furiosus has indicated that they both share an increased number of electrostatic interactions in comparison with other proteins (Day et al., 1992; Chan et al., 1995). A large number of extra ion pairs was also observed in the structure of the glyceraldehyde-3-phosphate dehydrogenase from the thermophilic Thermotoga maritima (Korndörfer et al., 1995). However, site-directed mutagenesis studies have so far failed to identify the specific ion pairs that contribute to the high thermostability of the latter enzyme (Tomschy et al., 1994).

Complementary to studying the role of specific residues, hybrid proteins in which large parts of the polypeptide chain are exchanged between homologous proteins offer the possibility of investigating the role of larger substructures in conferring functionality and stability to a protein. This approach has been applied to bacterial 3-isopropylmalate dehydrogenase from Thermus thermophilus and the archaeal glyceraldehyde3-phosphate dehydrogenase from Methanothermus fervidus, in which parts of mesophilic counterparts were introduced (Bis et al., 1990; Onodera et al., 1994). In addition, hybrid enzymı have been made between the bacterial Thermoactinomyce. intermedius phenylalanine dehydrogenase and Bacillus stearothermophilus leucine dehydrogenase (Kataoka et al., 1994). In all cases, novel dehydrogenases with characteristics from both parental enzymes were generated that allowed the localization of regions involved in the thermostability and binding of substrate and cofactor. We have extended this approach of producing hybrid proteins by exchanging domains in glutamate dehydrogenase (GDH). GDH is a well studied enzyme catalyzing the oxidative deamination of $\mathrm{L}$-glutamate to $\alpha$-ketoglutarate and ammonia, accompanied by the reduction of a single molecule of $\mathrm{NAD}^{+}$or $\mathrm{NADP}^{+}$(Smith et al., 1975). Primary sequences of $\mathrm{GDH}$ are available from a wide variety of organisms and have been used to arrange GDHs into two different families (Benachenhou-Lahfa et al., 1993). In general, GDH is a hexameric enzyme that consists of identical subunits. Recently, the 3-D structure of the hexameric GDH from Clostridium symbiosum, belonging to family $\mathrm{I}$, has been solved (Baker et al., 1992). Each subunit can be divided into two domains: domain I forms the core of the enzyme and binds the substrate, while domain II points outwards and binds the cofactor.

The most thermostable GDH is found in the hyperthermophilic archaeon P.furiosus with a half-life of $\sim 12 \mathrm{~h}$ at $100^{\circ} \mathrm{C}$ 
J.H.G.Lebbink et al.

Table I. Universal and gene-specific primers used for construction and DNA sequencing of the hybrid gdh genes

\begin{tabular}{|c|c|c|c|c|}
\hline Primer & Sequence & Position & & \\
\hline$B G 26$ & $5^{\prime}$-GGATAACAAT'TTCACACAGG-3' & pUC19 & $354,-373$ & $s$ \\
\hline BG27 & 5'-GTTTTCCCAGTCACGAC-3' & pUC19 & $492-476$ & A \\
\hline$B G 18$ & 5'-TGTCTTGCCCTTGAGGG-3' & Pfiuriosus gadh & $629-64.5$ & $A$ \\
\hline BG56 & 5'-TATACCTGCATCCACCAATGCTAAGAGGC-3' & P.furiosus gdh & $5.50-5,31$ & A \\
\hline BG57 & 5'-TATACCTGCAATTTGGTGGTTCTTTAGG-3' & C.difficile gelh & $539-5.57$ & $S$ \\
\hline BG58 & 5'-TATACCTGCTGGTGGATCACTTGGAAGAA-3' & P:furiosus gdh & $543-56.3$ & $s$ \\
\hline B(5) & 5'-TATACCTGCAAAGATCCACCAAATTCAACTG-3' & C.difficile gd/h & $547-5.33$ & A \\
\hline BG65 & $5^{\prime}$-CCACAAATAATGGCATG-3' & Pfiuriosus gollh & $448-464$ & $S$ \\
\hline BG66 & 5'-AGCTATAGAAGAAGTG-3' & Pfiutiosus gdh & $888-903$ & $S$ \\
\hline
\end{tabular}

The position of the primers is indicated in the sequence of pUC19 (Sambrook et al., 1989) or that of the different gall genes numbered from lirst base of the initiation start codon (Lyerly et al., 1991; Eggen at al., 1993). S, sense primer; A, antisense primer,

(Consalvi et al., 1991). Remarkably, GDH may comprise up to $20 \%$ of the total cell protein in P.furiosus and plays an important role in the removal of reduction equivalents (Kengen and Stams, 1994). We have cloned and characterized the gdh gene from P.furiosus and found it to encode a GDH belonging to family II (Eggen et al., 1993). Recently, we described the overexpression of the P.furiosus gdh gene in Escherichia coli and the formation of an active GDH in this host (Eggen et al., 1994). Here we present the characterization of the P.furiosus GDH produced by E.coli and a comparison with the enzyme isolated from P.furiosus. To study the role of the different domains in catalytic activity and stability, hybrid proteins were constructed between GDH from P.furiosus and the phylogenetically very distant mesophilic bacterium Clostridium difficile that share $52 \%$ amino acid sequence identity and both belong to the family II GDHs. Two hybrids were generated that contained either the substrate or the cofactor binding domain of P.furiosus or C.difficile GDH. The functionality, catalytic activity and both the chemical and thermal stabilities of these hybrids were compared with those of the parental enzymes produced in E.coli. An active archaeal-bacterial hybrid GDH was obtained with new properties.

\section{Materials and methods}

\section{Bacterial strains and media}

Escherichia coli TG1 [supE hsd $\triangle 5$ thi $\triangle$ (lac-proAB) F' (traD 35 proAB $^{+}$lacI lacZ $\triangle \mathrm{M} 15$ ); Gibson, 1984] was cultivated in LB-based medium at $37^{\circ} \mathrm{C}$. Escherichic coli $\mathrm{K} 12 \Delta \mathrm{H} 1 \Delta t r p$ [M72 Sm ${ }^{\mathrm{R}}$ lacZam $\triangle$ bio-uvrB $\triangle$ trpEA2( $\lambda$ Nam7-Nam53cI857 $\Delta \mathrm{H} 1)$; Bernard et al., 1979] was used in combination with expression plasmids containing the $\lambda P_{\mathrm{L}}$ promoter and was cultivated in the same medium.

\section{Enzymes, chemicals and primers}

Restriction enzymes and DNA modifying enzymes were purchased from Life Technologies Inc. and Pharmacia LKB Biotechnologies. Biochemicals of the highest purity were obtained from Boehringer and Fluka. Oligonucleotides were purchased from Pharmacia LKB Biotechnologies and are listed in Table I.

\section{DNA isolation and manipulation}

Small-scale plasmid DNA isolations, ligations, restrictions, DNA purification, agarose gel electrophoresis and transformation of E.coli were all performed as described by Sambrook et al. (1989). The plasmids $\mathrm{pUC18}$ and $\mathrm{pUC19}$ and the bacteriophages M13mp18 and M13mp19 (Yannisch-Perron et al., 1985) were used as cloning vectors. The expression vector pPLc2833 is a derivative of PPLc28 (Remaut et al.,
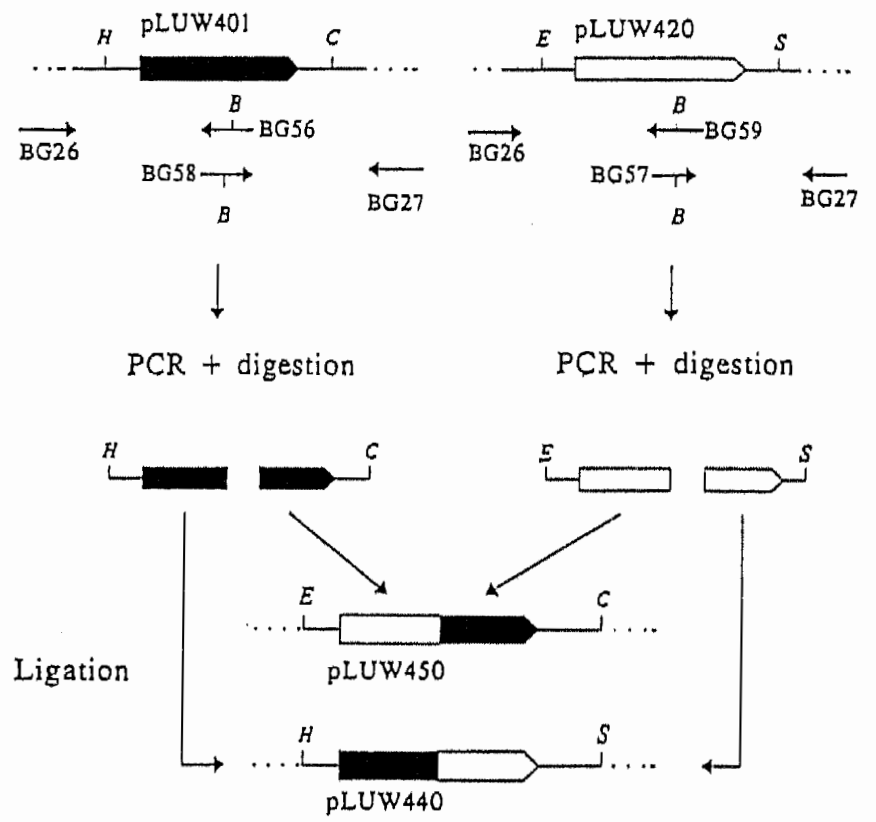

Fig. 1. Construction of hybrid genes. The physical maps of the parential plasmids pLUW401, eontaining the $1.6 \mathrm{~kb}$ Hirdll-mincll fragment with the P.furiosus gdh gene (black), and pLUW420, containing the $1.6 \mathrm{kl}$ licoRI SphI fragment with the Codifficile gdh gene (white). Relevant restriction sites are indicated: H, HindIII; C, HincII; E, EotRI; S, SphI; B, BspMI.

1981) containing additional $P$ stI-SalI-Xbal-SalI $-X \mid a l-B a m \mathrm{HI}$ restriction sites in between the unique BamHII and HindIII sites immediately downstream of the $P_{\mathrm{L}}$ promoter in pPLc2833. The hybrid genes were sequenced according to the dideoxy chain termination method (Sanger et al., 1977) using the T7 sequencing kit (Pharmacia). Universal and gene-specific oligonucleotides were used as primers (Table I).

Construction of the expression plasmids for wild-type and hybrid gdh genes

A $1.6 \mathrm{~kb}$ HindII-Hincll fragment containing the P.furiosus gdh gene was isolated from pLUW400) (Eggen et cl., 1994). Sticky ends were filled in using the Klenow fragment of E.coli DNA polymerase. The fragment was cloned into the blunted EcoRI restriction site of pPLc2833. The orientation of the P.furiosus gdh gene under the control of the $P_{\mathrm{l}}$ promoter was confirmed by restriction analysis, and the construct was denoted pLUW410. A $1.6 \mathrm{~kb}$ EcoRI-SphI chromosomal fragment containing the C.difficile gdh gene (Lyerly et al., 1991; kindly provided by Dr Lisa Barosso, Department of Anaerobic Microbiology, Virginia Polytechnic Institute and State University, Blacksburg, VA, USA) was cloned into an EcoRI-SphI linearized pUC18 vector to position the gdh gene under the control of the lacUV5 promoter, resulting in pLUW420. Hybrid 
genes were constructed according to a method described by Tomic et al. (1990) (Figure 1). Parts of the P.furiosus and C.difficile gelh genes encoding either domain I or II of GDH were amplified by PCR using 100) ng pLUW4()1 (pUC19 containing the P.furiosus grlh gene on a $1.6 \mathrm{~kb}$ HindIII-Hincll fragment) or pLUW420 as template and, for each reaction, $100 \mathrm{ng}$ universal vector primer and $200 \mathrm{ng}$ of a gene-specific primer with a Bsy MI site (Table I). Restriction endonuclease BspMI digests DNA at a short distance from its recognition site, allowing the formation of complementary overhanging ends on the PCR products that may be ligated. In addition to the template and primers, the $1(0) \mu l$ reaction mixtures contained 0.2 mM dNTPs, Taq DNA polymerase buffer, $5 \mathrm{mM}$ $\mathrm{MgCl}_{2}, 5 \mathrm{U}$ Taq DNA polymerase and were subjected to 30 cycles of amplification $\left(1.5 \mathrm{~min}\right.$ at $92^{\circ} \mathrm{C}, 2.5 \mathrm{~min}$ at $50^{\circ} \mathrm{C}$ and 3.5 min at $72^{\circ} \mathrm{C}$ ) on a programmable Ori-Block (New Brunswick Scientific). As determined by agarose gel electrophoresis, the amplification of the P.furiosus glutamate and cofactor binding domains resulted in the expected 0.6 and $1.0 \mathrm{~kb}$ products, respectively. Amplification of the C.difficile glutamate and cofactor binding domains also resulted in the expected $(0.6$ and $1.0 \mathrm{kh}$ products, respectively. Each product was digested with BspMI and HindlI, Hincll, EcoRI or Sphl that cut in the polylinker sequence (Figure 1). A three-point ligation of the 5' P. furiosus golh gene fragment and the $3^{\prime}$ C.difficile galh gene lagment into HindlI-Sphl linearized pUC19 resulted in pLUW44(). A three-point ligation of the $5^{\prime}$ C.difficile gdh gene fragment and the 3' P.furiosus galh gene fragment into EcoRI-Hincll linearized pUCl8 resulted in pLUW45(). All constructions were performed in E.coli TG1.

\section{Purification of GDH}

GDH was purified from P.furiosus as described previously (Consalvi et al., 1991). To isolate P.furiosus GDH from E.coli, strain $\mathrm{K} 12 \Delta \mathrm{H} 1 \Delta \mathrm{rp}$ harboring pLUW410 was cultured at $28^{\circ} \mathrm{C}$ until an $O D_{(0)}$ of $(0.5$ was reached and incubated for another $2 \mathrm{~h}$ at $42^{\circ} \mathrm{C}$. Subsecpuently, the culture was centrifuged for 10 min at $5(0)(0)$ r.p.m. and $4^{\circ} \mathrm{C}$, medium was discarded and cells were resuspended in $20 \mathrm{mM}$ potassium phosphate buffer, pH 6.5, $1 \mathrm{mM}$ EDTA (buffer A) containing $1 \mu \mathrm{g} / \mathrm{ml}$ DNase. The suspension was sonified using a Branson sonifier and cell debris was removed by centrifugation at $13(0) 0$ r.p.m. for 10 min. The resulting supernatant was incubated for $10 \mathrm{~min}$ at 9()$^{\circ} \mathrm{C}$ and precipitated proteins were removed by centrifugation for another $10 \mathrm{~min}$ at 1.3()()$(\mathrm{)}) \mathrm{p} . \mathrm{m}$. The sample was dialyzed against butfer $A$ and applied to a $60 \mathrm{ml}$ Matrex gel Red A column (Amicon) equilibrated with buffer A. After extensive washing with buffer $A$, GDH was eluted from the column using a step gradient of $120 \mathrm{ml}$ of $(0.10,0.25,0.35$ and $1.00 \mathrm{M} \mathrm{NaCl}$ in bulfer $\mathrm{A}$. The fractions $0.25-1.00 \mathrm{M}$ were pooled, concentrated and dialyzed against ().1 M sodium phosphate buffer, pH 7.(), and contained pure GDH as judged by SDS-PAGE (12\% polyacrylamide).

To purify C.difficile and the P.furiosus-C.difficile hybrid GDH, E.coli TG1 cultures harboring either pLUW420 or pLUW440 were centrifuged for $10 \mathrm{~min}$ at 5000 r.p.m. and $4^{\circ} \mathrm{C}$. The medium was discarded and the cells were resuspended in $10 \mathrm{mM}$ potassium phosphate buffer, pH 7.2, $1 \mathrm{mM}$ EDTA (buffer B) containing $1 \mu \mathrm{g} / \mathrm{ml}$ DNase. The cells were broken in a French press under 1000 atmospheres pressure and cell debris was removed by centrifugation at 5000 r.p.m. for 20 min. Crude extracts were dialyzed against buffer $B$ and applied to a $Q$ Sepharose column (Pharmacia) equilibrated with buffer B. The column was washed until a stable baseline was recorded.
The elution of GDH was performed by applying a gradient of ().0-1.0 $\mathrm{M} \mathrm{NaCl}$ in buffer B. Active liactions were pooled and dialyzed against buffer B. Ammonium sulfate was added up to $40 \%$ saturation and the precipitated proteins were removed by centrifugation for $10 \mathrm{~min}$ at $13(0)(0)$ r.p.m. The sample was loaded onto a phenyl Sepharose column (Pharmacia) equilibrated with $40 \%$ ammonium sulfate saturated buffer $B$. After extensive washing using equilibration buffer, elution was performed by a $4(0-0 \%$ ammonium sulfate gradient in buffer B. Active fractions were pooled, dialyzed against $1.0 \mathrm{mM}$ potassium phosphate buffer, pH 6.8 (buffer $C$ ), and applied to a hydroxyl apatite column equilibrated with buffer $C$. After extensive washing, elution was performed by applying a 1.0 mM-1.0 $\mathrm{M}$ gradient of potassium phosphate, pH 6.8 . Active fractions were pooled and dialyzed against (0.1 M sodium phosphate buffer, pH 7.0. "To obtain pure P.furiosus GDH produced by E.coli without heat incubation, the protocol described for the C.difficile GDH purification was followed. The purity of the samples was analyzed by SDS-PAGE.

\section{GDH activity asisay}

GDH activity was assayed using a double-beam Kontron Uvikon 860 spectrophotometer at $340 \mathrm{~nm}$ and $25^{\circ} \mathrm{C}$. The $1 \mathrm{ml}$ standard assaly reaction mixtures (reverse reaction, unless mentioned otherwise) eontained $100 \mathrm{mM}$ potassium phosphate buffer, pH 7.6, and ().75 mM $\alpha$-ketoglutarate, $75 \mathrm{mM}$ ammonia and $100 \mu \mathrm{M}$ NADPH for P. furiosus GDH; $4 \mathrm{mM} \alpha$-ketoglutarate, $600 \mathrm{mM}$ ammonia and $0.2 \mathrm{mM} \mathrm{NADH}$ for C.difficile GDH; and $6 \mathrm{mM} \alpha$-ketoglutarate, $900 \mathrm{mM}$ ammonia anc (). $2 \mathrm{mM}$ NADH for the hybrid GDH. Fixed substrate concentrations for glutamate oxidation (forward reaction) were $6 \mathrm{mM}$ L-glutamate and $0.25 \mathrm{mM}$ NADP for P.furiosus GDH; $50 \mathrm{mM}$ L-glutamate and $4 \mathrm{mM}$ NAD for C.difficile GDH; and $60 \mathrm{mM}$ l.-glutamate and $6 \mathrm{mM}$ NAD for the hybrid GDH. The amount of enzyme was varied to obtain a rate of $\sim(0.0) \Delta \Delta$ absorbance/ min. We define $1 \mathrm{U}$ of enzyme activity as the amount of enzyme which produces I Hmol of product per minute under standard conditions. Kinetic parameters were calculated by a nonlineall regression analysis of the clata using ENZFIT'TER (Leatherbarrow, 1987). For each calculation, at least eight velocity/substrate data pairs were used. Substrate specificity was studied by measuring GDH activity in the presence of 20) and $100 \mathrm{mM}$ D-glutamate, glycine, L-leucine, L-threonine, L-alsparagine, L-valine, L-proline, L-aspartate, L-glutamine or L-norvaline and 5 and $25 \mathrm{mM}$ oxaloacetate, glyoxylate, 2-oxobutyrate, 2-ox(-m-methyl-pentanoate, pyruvate or 2-oxovalerate.

\section{Protein analysis}

Protein concentrations were determined using Bradford reagent (Bio-Rad, Veenendaal, The Netherlands) with bovine serum albumin as a standard. Protein concentrations of pure samples were deternined using the following extinction coefficients at $280 \mathrm{~nm}$, calculated as described by Gill and von Hippel (1989): $\varepsilon_{\mathrm{m}}=82500 \mathrm{M}^{-1} \mathrm{~cm}^{-1}$ for P.furiosus GDH, $\varepsilon_{\mathrm{m}}=66000 \mathrm{M}$ ${ }^{1} \mathrm{~cm}^{-1}$ for C.difficile GDH and $\varepsilon_{\mathrm{m}}=86910 \mathrm{M}^{-1} \mathrm{~cm}^{-1}$ for the hybrid GDH. Protein bands on SDS-PAGE gels were scanned and quantified using an Image Analysis System (Visionary, Fotodyne) equipped with ImageQuant (Molecular Dynamics) software. UV absorbance spectra were recorded at 2()$^{\circ} \mathrm{C}$ on a Perkin Elmer Lambda 16 spectrophotometer. The electrophoretic separation of proteins under native conditions was performed on $8 \%$ running gels. Apparent molecular masses were determined by an analytical gel filtration using a Superose 12 
column (Pharmacia) as described previously (Consalvi et al., 1991). Immunodetection was performed using antibodies raised against purified pyrococcal GDH (Eggen et al., 1993). Protein microsequencing was carried out by cyclic Edman degradation on an Applied Biosystems amino acid sequenator model 477A (Eurosequence, Groningen, The Netherlands) using protein samples dialyzed against $\mathrm{H}_{2} \mathrm{O}$.

\section{Effect of guanidinium chloride $(\mathrm{GdmCl})$ on spectral properties}

The enzymes $(80 \mu \mathrm{g} / \mathrm{ml})$ were incubated at $20^{\circ} \mathrm{C}$ for $24 \mathrm{~h}$ in $20 \mathrm{mM}$ phosphate, $\mathrm{pH} 7.0$, in the presence of increasing concentrations of $\mathrm{Gdm} C \mathrm{Cl}$ ranging from 0.0 to $7.2 \mathrm{M}$. UV absorbance spectra were monitored at $20^{\circ} \mathrm{C}$ in a Perkin Elmer Lambda 16 spectrophotometer. Fluorescence properties were studied at $20^{\circ} \mathrm{C}$ in a Perkin Elmer LS50B fluorimeter. Excitation was performed at $295 \mathrm{~nm}$ and emission was monitored at 300 $400 \mathrm{~nm}$. Far-UV CD spectra $(210-250 \mathrm{~nm})$ were recorded at $20^{\circ} \mathrm{C}$ in a Jasco $\mathrm{J} 500 \mathrm{~A}$ spectropolarimeter using a $0.2 \mathrm{~cm}$ cuvette. Fluorescence emission at $342 \mathrm{~nm}$ and observed ellipticities at $222 \mathrm{~nm}$ were normalized according to Pace (1986).

\section{Thermostability}

Enzyme thermostability was studied at $63,65,67$ and $69^{\circ} \mathrm{C}$ for C.difficile GDH and hybrid GDH $(5-50 \mu \mathrm{g} / \mathrm{ml})$ and at 90 and $105^{\circ} \mathrm{C}$ for P.furiosus GDH $(50 \mu \mathrm{g} / \mathrm{ml})$. The enzymes were incubated in $20 \mathrm{mM}$ sodium phosphate, $\mathrm{pH} 7.0$, in sealed glass tubes for 0-24 h. Residual enzyme activity (forward reaction in the case of C.difficile GDH and hybrid GDH) was assayed at $25^{\circ} \mathrm{C}$ with respect to a control kept at room temperature. Slopes of first-order inactivation plots yielded rate constants for inactivation. These rate constants were used to calculate the free energy of the transition state for thermal inactivation $\left(\Delta G^{*}\right)$ according to Segel (1975).

\section{Results}

\section{Expression of the Pfuriosus gdh gene in E.coli}

High level overproduction of the P.furiosus GDH was obtained by cloning the Pffuriosus gdh gene under the control of the $\lambda$ $P_{\mathrm{L}}$ promoter on the expression vector pPLc2833 and introducing the resulting plasmid pLUW410 into E.coli $\Delta \mathrm{H} 1 \Delta t r p$ that carries a temperature-sensitive c1857 repressor. Incubation at $42^{\circ} \mathrm{C}$ inactivates the cl857 repressor and the P.furiosus galh gene is expressed. The P.furiosus GDH produced in this system amounted to up to $20 \%$ of the total cell protein in E.coli and showed a subunit molecular mass of $46 \mathrm{kDa}$, similar to $\mathrm{GDH}$ isolated from P.furiosus cells (Figure 2, lanes 2 and 3). Heat incubation of the cell-free extract at $90^{\circ} \mathrm{C}$ for $10 \mathrm{~min}$ and the subsequent removal of precipitated E.coli proteins resulted in highly purified $P$. furiosus GDH (Figure 2, lane 4). The residual traces of E.coli proteins were removed by bioaffinity chromatography on a Matrex gel Red A column (Figure 2, lane 5). The enzyme showed a strong cross-reaction with antibodies raised against purified pyrococcal GDH, and native PAGE and subsequent immunoblotting revealed that at least $90 \%$ of the GDH was in the hexameric conformation (results not shown). $\mathrm{N}$-terminal sequencing (results not shown) indicated that $>98 \%$ of the P.furiosus GDH produced in E.coli contained its Nterminal methionine that is also present in the majority of GDH purified from P.furiosus (Maras et al., 1994).

Total GDH activity of the incubated cell-free extract samples increased $\sim 3$-fold during the heat treatment, indicating an activation of P:furiosus GDH or the inactivation of inhibitors
1
2
3
4
5

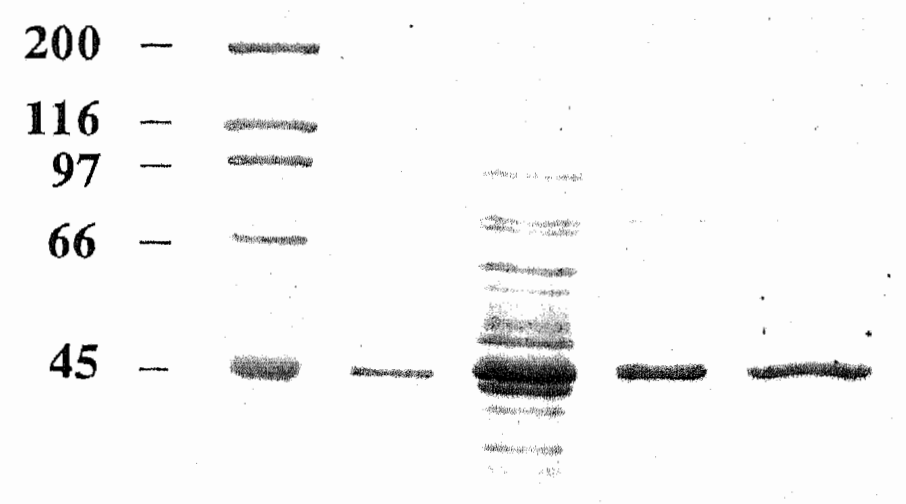

$31-$

\section{$21-$}

Fig. 2. SDS-PAGE of P.furiosus, C.difficile and hybrid GDH. Lane 1, brond range molecular weight marker (Bio-Rad); lane 2, GDH isolated liom P.furiostus; lanes 3-5, E.coli harboring pLUW410 cell-free extract (lane 3), supernatant after heat incubation (lane 4) and Matrex gel Red A fraction (lane 5).

present in the cell-free extract. The latter possibility was excluded because the addition of cell-free extract from an E.coli culture containing pPLc2833 to the reaction mixture did not affect the specific activity of purified Pfirriosus GDH. Pyrococcus furiosus GDH purified from E.coli without heat treatment showed an apparent molecular mass of $260 \mathrm{kDa}$ on a gel permeation column. Heat treatment of this $260 \mathrm{kDa}$ fraction increased its activity $\sim 10$-fold, indicating that P.furiosus GDH is present as partially active hexamers in the E.coli cell-free extract which attained a fully active conformation upon incubation at $90^{\circ} \mathrm{C}$. No differences in secondary and tertiary structure between the partially and fully active conformations could be detected in UV absorbance difference spectra, fluorescence emission and far-UV $\mathrm{CD}$ spectra (results not shown). These results indicate that P.furiosus GDH produced in E.coli is identical to that produced in P.furiosus, allowing for its use in protein engineering studies.

\section{Construction and expression of hybrid galh genes}

Hybrid gdh genes were constructed containing either the substrate binding domain I or the cofactor binding domain II of P.furiosus $\mathrm{GDH}$ and the complementary domain of C.difficile GDH. The latter GDH was chosen because the family II C.difficile and P.furiosus GDHs share 52\% identical amino acid residues (Lyerly et al., 1991; Eggen et al., 1993). In addition, there are considerable differences in the thermal stability and kinetic properties of the two enzymes (see below). To maximize the possibility of obtaining hybrid enzymes with catalytic activity, the fusion was located in between two fully conserved glycine residues, that in the known GDH structure of C.symbiosum are located in the loop between $\beta$-sheet $f$ and $\alpha$-helix 9 connecting the two domains (corresponding to residues Gly200 and Gly201 in C.symbiosum; Baker et al., 1992).

Based on two pUC19 derivatives, pLUW401 and pLUW420, carrying the P.furiosus and C.difficile gdh genes, respectively, 


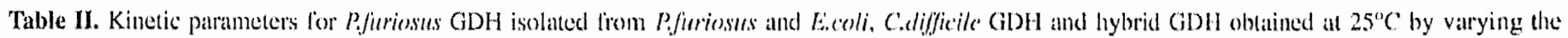
concentration of the respective substrate while keeping all other patamelers tixed

\begin{tabular}{|c|c|c|c|c|c|c|c|c|}
\hline \multirow[t]{2}{*}{ Substrate } & \multicolumn{2}{|c|}{ Pfirtosus GDH } & \multicolumn{2}{|c|}{ P.furiosus GDH (E,cosi $)$} & \multicolumn{2}{|c|}{ C.difficile GDH } & \multicolumn{2}{|c|}{ Hybrid GDH } \\
\hline & $\begin{array}{l}\overline{K_{11}} \\
(\mathrm{mM})\end{array}$ & $\begin{array}{l}\text { Calalylic efliciency" } \\
\left(\text { min }^{-1} \text { mg }\right.\end{array}$ & $\begin{array}{l}K_{\ln } \\
(m \mathrm{M})\end{array}$ & $\begin{array}{l}\text { Catulytic efliciency } \\
\text { (min }{ }^{-1} \mathrm{mg}^{-1} \text { ) }\end{array}$ & $\begin{array}{l}\overline{K_{\mathrm{m}}} \\
(\mathrm{niM})\end{array}$ & $\begin{array}{l}\text { Catilytic efliciencya } \\
\text { (min' }{ }^{-1} \text { mg }{ }^{-1} \text { ) }\end{array}$ & $\begin{array}{l}K_{\mathrm{m}} \\
(\mathrm{mM})\end{array}$ & $\begin{array}{l}\text { Cotalytic efliciency" } \\
\text { (min } \text { mg }^{-1} \text { ) }\end{array}$ \\
\hline 1.-Glutamate & $1 .()$ & 5.5 & - & - & 2.7 & 28 & 18.1 & $0 .\left(0^{9}\right)$ \\
\hline$\alpha$-Ketoglaturate & 0.0 .39 & 40.5 & 0.026 & $6(1) 0$ & 0.16 & 59106 & 0.74 & 225 \\
\hline \multirow[t]{2}{*}{ Ammonia } & $4.6^{6}$ & 3.4 & $5.1^{17}$ & 1.9 & $\left.12\right|^{11}$ & 7.9 & $228^{4}$ & 0.74 \\
\hline & $24.0^{\circ}$ & 1.1 & $30 .\left(0^{c}\right.$ & 0.6 & & & & \\
\hline NAD & $\ldots$ & $\ldots$ & $\ldots$ & - & 0.0 .5 & 145 & 1.08 & 12 \\
\hline NADH & - & - & $\ldots$ & - & 0.04 .3 & 27621 & 0.047 & 3932 \\
\hline NADPH & $0.0(0) 30$ & 6.5 .33 & 0,0050 & 46000 & ND & $\mathrm{ND}$ & ND & ND \\
\hline
\end{tabular}

ND, not detectable; - not determined.

" $V_{\max } / K_{\mathrm{m}}$.

bi,25-20) mM ammonia.

(3)-150) mM ammonia.

dy-900 $\mathrm{mM}$ ammonia.

two reciprocal hybrid genes were constructed following a procedure described previously (Tomic et al., 1990). The essential reactions included PCR amplification with appropriate primers that created a BspMI site (Table I) followed by digestion with BspMI and ligation into linearized pUC19 (Figure 1). The complete DNA sequence of each hybrid gene was determined and found to be identical to that expected from the P.furiosus and C.difficile gdh gene secpuences (Lyerly et al., 1991; Eggen et al., 1993). The resulting plasmids pLUW440) and pLUW450 (Figure 1) were each introduced into E.coli strain TG1. Cell-free extracts were assayed for GDH activity and compared with those obtained with the parental plasmids carrying the wild-type genes.

The activity of the hybrid GDH specified by pLUW440, containing the substrate binding domain I of P.furiosus and the cofactor binding domain II of C.difficile, could be detected using $\mathrm{NAD}(\mathrm{H})$ as cofactor, No activity could be detected with $\operatorname{NADP}(\mathrm{H})$. This P.furiosus-C.difficile hybrid enzyme amounted to up to $1 \%$ of total cell protein according to SDS-PAGE, possessed a subunit molecular mass of $46 \mathrm{kDa}$ like the P.furiosus GDH, and showed a weak cross-reaction with antibodies raised against pyrococcal GDH (data not shown).

The complementary hybrid GDH specified by pLUW450, containing domain I of C.difficile GDH and domain II of Pffuriosus GDH, also amounted to up to $1 \%$ of total cell protein according to SDS-PAGE, had a molecular mass of $45 \mathrm{kDa}$ like C.difficile GDH, and showed a strong crossreaction with the pyrococcal GDH antibodies (results not shown). However, despite its efficient production, this hybrid GDH showed no activity above the E.coli background GDH activity. In contrast, active C.difficile GDH was highly overproduced in E.coli TG1 harboring pLUW420, the parental plasmid that only differs from pLUW450 by the absence of P.furiosus DNA encoding domain II (results not shown; Lyerly et al., 1991).

The active P.furiosus-C.difficile hybrid GDH specified by pLUW440 and the C.difficile GDH were subsequently purified to homogeneity, as judged by SDS-PAGE, and used for further characterization.

\section{Kinetic parameters and substrate specificity}

Pyrococcus furiosus GDH was purified from either P.furiosus or E.coli and used to determine the kinetic parameters as well as the substrate and cofactor specificities that were compared with each other and those obtained with purified Codlifficile or P. furtosus-C.difficile hybrid GDH (Table II).

Similar $K_{\mathrm{m}}$ values for $\alpha$-ketoglutarate, ammonia and NADPH were obtained with Pfuriosus GDH isolated from P.furiosus and E.coli. Even the Lineweaver-Burk plots that were obtained with the P:furtosus GDH from either souree showed similar curvature for ammonia, indicating that at low eoncentrations the affinity for ammonia was higher than at high concentrations. The affinity for ammonia of the Paturiosus GDH from both sources at $25^{\circ} \mathrm{C}$ was the same as that reported previously at $60^{\circ} \mathrm{C}$ (Consalvi et al., 1991). However, the $K_{\mathrm{m}}^{\prime}$ values of the P.furiosus GDH for NADPH and notably $\alpha$-ketoglutarate appeared to be temperature dependent because those found it $25^{\circ} \mathrm{C}$ were four and nine times lower, respectively, than those reported previously at $60^{\circ} \mathrm{C}$ (Consalvi et $a l$., 1991). The calculated $V_{\text {max }} / K_{\mathrm{m}}$ values of the P.furiosus GDH isolated from either P:furiosus or E, coli were similar, indicating that this GDH showed a host-independent specific activity and efficiency.

The purified C.difficile GDH followed Michadis-menten kinetics for NAD, NADH and ammonia. No activity was found with phosphorylated cofactors. For L-glutamale and $\alpha$-ketoglutarate, substrate inhibition was observed ahove 50 and $4 \mathrm{mM}$, respectively. Clostridium diffic ile GDH was unable to convert any of the tested substrate analogs.

The hybrid Pfuriosis-C.difficile GDH also followed Michaelis-Menten kinetics only for NAD and NADH. For 1-glutamate and $\alpha$-ketoglutarate, substrate inhibition was observed for this enzyme above 60 and $6 \mathrm{mM}$, respectively. No saturation was observed with the hybrid GDH for ammonia up to $900 \mathrm{mM}$. $V_{\text {max }} / K_{\mathrm{m}}$ values indicated that the hybrid GDH was much less efficient than both parental enzymes. Substrate binding appeared to be aflected in the hybrid because $K_{\mathrm{m}}$ values for glutamate, $\alpha$-ketoglutarate and ammonia were much higher than for both parental enzymes (Table II). In addition, the hybrid was found to be more specific than GDH isolated from P.furiosus because it was not able to convert L-norvaline or 2-oxovalerate, while the P.furiosus GDH was able to utilize any of these substrate analogs (Consalvi ot al., 1991). Comparable $K_{m}$ values for NAD and NADH were found with the hybrid and C.difficile GDH, while neither showed activity with the phosphorylated cofactor. The identical cofactor affinity and specificity of the P,furiosus-C.difficile hybrid and the C.difficile GDH indicate that these properties are solely determined by the cofactor binding domain. 


\section{Optimum temperature}

Pyrococcus furiosus $\mathrm{GDH}$ isolated from E.coli showed an identical temperature optimum of $100^{\circ} \mathrm{C}$ as the enzyme isolated

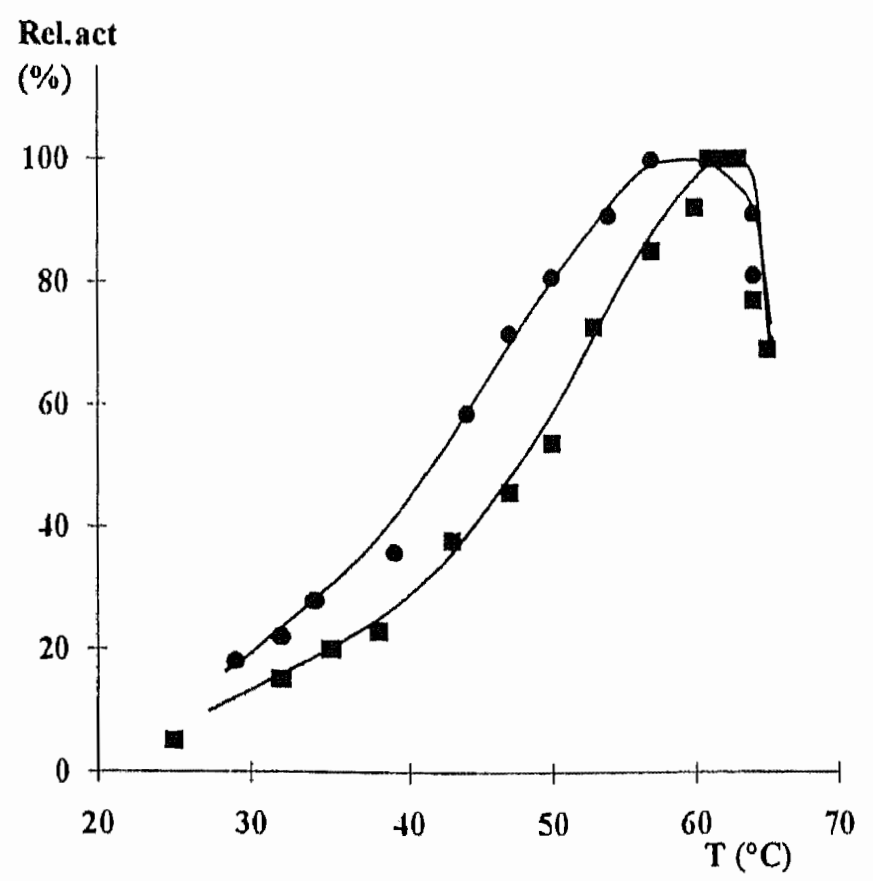

Fig. 3. Temperature dependence of C.difficile GDH ( $)$ and hybrid GDH (E) for glutamate breakdown.

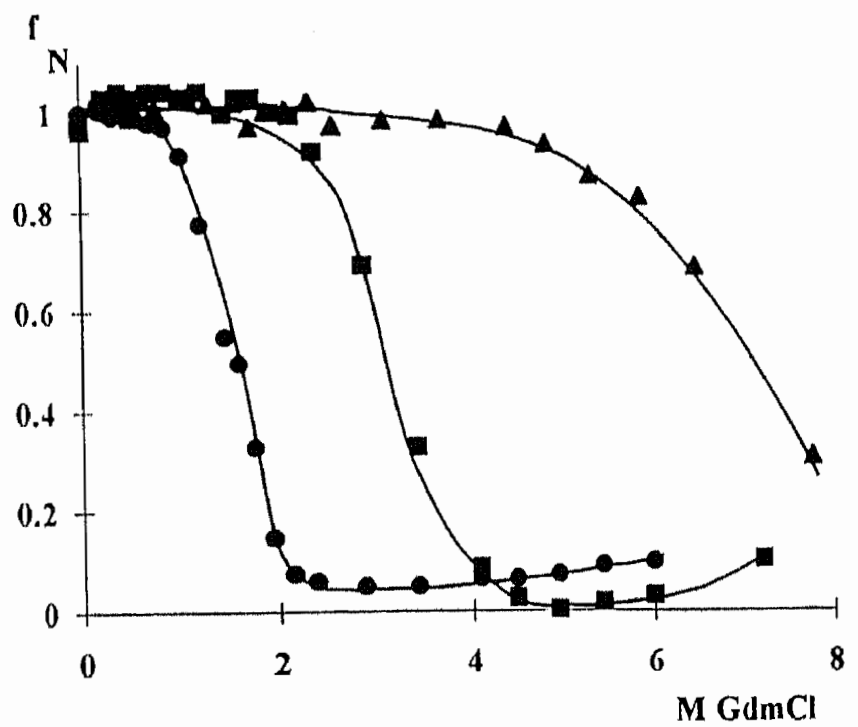

Fig. 4. GdmCl-induced denaturation of C.difficile GDH (-), hybrid GDH () and P.furiosus GDH ( $\boldsymbol{\Delta})$ followed by fluorescence emission at $342 \mathrm{~nm}$. The fraction of GDH present in the native conformation $\left(f_{N}\right)$ is ploted against the $\mathrm{GdmCl}$ concentration. from Pfuriosus (Consalvi et al., 1991; results not shown). This temperature optimum was much higher than that observed with the Pfuriosus-C.difficile hybrid GDH that showed a similar optimum to the $C$.difficile GDH for glutamate formation $\left(56-63^{\circ} \mathrm{C}\right)$. For glutamate breakdown, the optimum temperature of the hybrid GDH was slightly higher than that of C.difficile GDH (61-64 and 57-61 $\mathrm{C}$, respectively; Figure 3). This indicates that exchange of the P.furiosus cofactor binding domain for that from C.difficile lowers the optimum temperature of the resulting hybrid enzyme to the level obtained with the GDH from the mesophilic parent.

\section{Influence of $\mathrm{GdmCl}$ on spectral properties}

The effect of $\mathrm{GdmCl}$ on fluorescence emission intensity and ellipticity of the P.furiosus, C.difficile and hybrid P.furiosusC.difficile GDHs was studied. Identical denaturation curves were obtained with both spectroscopic technicues. Transition midpoints were found at $6.6,3.2$ and $1.5 \mathrm{M} \mathrm{GdmCl}$ for P.furiosus GDH, the hybrid and C.difficile GDH, respectively (Figure 4). The loss of secondary structure was accompanied by a loss of ability to regain catalytic activity after dilution of the denaturant because transition midpoints found by fluorescence and $C D$ were similar to those found in reactivation experiments in which $\mathrm{GdmCl}$ was removed after $24 \mathrm{~h}$ of incubation by an at least 50-fold dilution (data not shown).

\section{Thermostability}

The thermostability of P. furiosus GDH purified from P.furiosus or E.coli was studied at 90 and $105^{\circ} \mathrm{C}$ (Table III). The $260 \mathrm{kDa}$ gel permeation fraction containing P.furiosiss GDH that was purified from E.coli without heat treatment lost its activity almost completely within several minutes of incubation at $105^{\circ} \mathrm{C}$ (data not shown). However, Pyrococcus furiosus GDH that was purified from E.coli using heat incubation showed an initial fast inactivation (loss of $>50 \%$ activity within several minutes) and a second much slower inactivation at $105^{\circ} \mathrm{C}$. The half-life of this second inactivation process was similar to that of GDH purified from P.furiosus $(\sim 1 \mathrm{~h}$; Table III). At $90^{\circ} \mathrm{C}$, there was only a small initial loss of activity of the heat-treated GDH purified from E.coli. Pyrococcus furiosus GDH isolated from E.coli showed a similar half-life at this temperature to that isolated from P:furiosus ( $6 \mathrm{~h}$; Table III).

The thermostability of C.difficile GDH and the P.furiosusC.difficile hybrid GDH was determined at $63,65,67$ and $69^{\circ} \mathrm{C}$. At all these incubation temperatures the hybrid PfuriosusC.difficile GDH showed a 2-fold shorter half-life than the C.difficile GDH, irrespective of the protein concentration (data not shown). At $65^{\circ} \mathrm{C}$, this difference in stability amounted to up to $1.89 \mathrm{~kJ} \mathrm{~mol}^{-1}$ (Table III). Both P.furiosus and C.difficile GDH remained soluble after thermal inactivation, whereas centrifugation of the thermally inactivated hybrid resulted in the

Table III. Half-life and $\Delta G^{\ddagger}$ values for the thermal inactivation of P.furiosts GDH isolated from P.furiosus and E.coli at 90 and $105^{\circ} \mathrm{C}$, and of C.difficile $\mathrm{GDH}$ and hybrid $\mathrm{GDH}$ at $65^{\circ} \mathrm{C}$

\begin{tabular}{|c|c|c|c|c|c|c|}
\hline & \multicolumn{2}{|c|}{$65^{\circ} \mathrm{C}$} & \multicolumn{2}{|c|}{$90^{\circ} \mathrm{C}$} & \multicolumn{2}{|c|}{$105^{\circ} \mathrm{C}$} \\
\hline & $\begin{array}{l}t_{1 / 2} \\
(\mathrm{~h})\end{array}$ & $\begin{array}{l}\Delta G^{*} \\
\left(\mathrm{~kJ} \mathrm{~mol}^{-1}\right)\end{array}$ & $\begin{array}{l}t_{1 / 2} \\
(\mathrm{~h})\end{array}$ & $\begin{array}{l}\Delta G^{\sharp} \\
\left(\mathrm{kJ} \mathrm{mol}^{m-1}\right)\end{array}$ & $\begin{array}{l}t_{1 / 2} \\
(\mathrm{~h})\end{array}$ & $\begin{array}{l}\Delta G^{\dagger} \\
\left(\mathrm{kJ} \mathrm{mol}^{-1}\right)\end{array}$ \\
\hline C.difficile GDH & 5.1 & 111.70 & - & - & - & - \\
\hline Hybrid GDH & 2.6 & 109.81 & - & - & - & - \\
\hline P. furiosus GDH & - & - & 5.5 & 120.41 & 1.20 & 120.72 \\
\hline P. furiosus GDH (E.coli) & - & - & 6.4 & 120.87 & 0.86 & 119.68 \\
\hline
\end{tabular}

$\Delta G^{\dagger}$ values were calculated according to Segel (1975), -, not determined. 
complete precipitation of the aggregated enryme presumabiy because of the exposure of buried hydrophobic residues.

\section{Discussion}

We have reported previously the functional expression of the P.furiosus galh gene in E.coli under the control of the $\lambda P_{\mathrm{t}}$. promoter (Eggen et al., 1994). After further optimization described here, up to $20 \%$ of the total E.coli cell protein could be iclentified as P.furiosus GDH. After heat treatment, the enzyme was fully active, suggesting that it needs a temperature closer to the in vivo growth optinum of P.furiosias to be able to adopt its correct conformation. Pyrococcus furiosus GDHs isolated from P.furiosus and E.coli have similar apparent molecular weights, N-terminal sequences, subunit compositions, specific activities, thermoactivities, kinetic parameters and both chemical and themal stabilities. This confirms that the overproduced enzyme can be used to study molecular adaptations to high temperatures.

Pyrococcus furiosus GDH produced by E.coli appears to be partially active in untreated cell-free extract. Native PAGE and subsequent immunodetection showed that at least $90 \%$ of the GDH formed in E.coli is present in a hexameric conformation. Furthermore, the hexameric GDH fraction obtained by gel filtration showed a clear increase in specific activity after heat treatment. These results strongly suggest the presence of partially active, hexameric GDH in the E.coli cell-free extract, which upon heat treatment arranges into a fully active structure. Furthermore, the enzyme isolated from E.coli without heat treatment is not fully thermostable because it showed an almost complete loss of activity upon incubation at $105^{\circ} \mathrm{C}$, while the heat-incubated enzyme showed a considerably longer half-life (almost $1 \mathrm{~h}$ ) at this temperature. This implies that either the P.furiosus GDH is present in E.coli in two conformations, one fully thermostable and one less thermostable, or that the enzyme always assumes a partially active conformation which is lost during its purification from P.furiosus but maintained in the purification method applied to E.coli. At present, we cannot discriminate between these two possibilities. It was reported recently that the expression of the P.furiosus galh gene as a transcriptional and translational fusion using the $\mathrm{T} 7$ system in E.coli resulted in $\sim 15 \%$ GDH of total cell protein. However, this overproduced P.furiosus GDH consisted of $50 \%$ inactive monomeric enzyme that assembled into hexamers upon heat incubation (Diruggiero and Robb, 1995). The correct hexameric subunit assembly in E.coli, which is reported here when the P.furiosus gallh gene is expressed under the control of the $\lambda P_{1}$. promoter, might be caused by the activity of E.coli heat-shock proteins that are induced upon incubation at $42^{\circ} \mathrm{C}$. However, more trivial explanations may also account for the previously observed incorrect folding in E.coli because the P. furiosus galh gene used in those studies was PCR amplified and may contain unforeseen mutations (Diruggiero and Robb, 1995).

Exchanging parts of the polypeptide chain between homologous enzymes with different characteristics can be very useful in studying the role and localization of residues involved in achieving thermostability. The cloning and successful expression of the P.furiosus gdh gene allowed us to exchange domains between this GDH and GDH from any other organism to study the effects on its functionality and stability. The phylogenetically very distant mesophilic bacterium C.difficile was chosen to be the partner in the domain exchange. The gene fusion was located between two conserved glycine residues in the loop connecting the two domains, so as to disturb as little as possible the folding of the resulting hybrids in comparison with the parental enzymes.

The activity of the C.difficile P. fartosus hybrid GDH, containing the substrate binding domain I of C.difficile GDH and the cofactor binding domain II of P. furiosws GDH, could not be detected above the Eacoli background, although it was clearly present in E.coli cell-free extract as judged by SDS PAGE and immunoblotting. Apparently, the correct folding and/or assembly into an active hexameric structure was impaired in this mutant. In contrast, the complementary P. furiosus-C.difficile hybrid, with the substrate binding domain I from P.firiosus GDH and the colactor hinding domain II of C.difficile GDH, showed significant GDH activity when produced in E.coli. According to gel permeation chromatography, it had the same apparent molecular weight as P: fitriosus.s GDH and C.difficile GDH, indicating a hexameric assembly similar to that of the parental enzymes. The Pfiuriosus C.difficile hybrid enzyme is less efficient than both parental GDHs, as indicated by its kinetic parameters. Similar affinitics for NAD and NADH for the hybrid and C.difficile GDH, and the inability to use the phosphorylated cofactor, indicate that binding of the cofactor is not altered in the hybrid that contains domain II from C.difficile GDH. This result agrees with the structures of the binary and tertiary eomplexes of C.symbiosum GDH, which show that the eofactor is almost exclusively bound by domain II (Baker et al., 1992; Stillman et al., 1993). Moreover, this result inclicates that the colactor binding domain Il of GDH is structurally independent of domain I with respect to the binding of the cofactor. A similar independent activity was observed with the eofactor bincling domain of the glyceraldehyde-3-phosphate dehydrogenase from T.maritima which, after overproduction in E.coli, retained its eapacicy to bind NAD and NADH (Jecht ef al., 1994). Both dehydrogenases show a similar domain arangement, with the main difference being the orientation of the cofactor binding domain that is C-terminal in CoH and N-terminal in glyecraldehyde-3. phosphate dehydrogenase.

The low catalytic efficiency of the P.furiosus-C.difficile hybrid enzyme is very likely caused by less eflicient substrate binding, as indicated by the higher $K_{\mathrm{m}}$ values for t-glutamate and $\alpha$-ketoglutarate as well as ammonia compared with both parental enzymes. Interactions in the poeket on the surface of domatin I, where the substrate side chain is bound (Stillman et al., 1993), are not expected to be changed significantly because they are solely made by residues from domain I and the hybrid is even more specific towards substrate analogs than P.fariosus GDH. It is possible that the interdomain interactions involved in positioning the two domains in the correct orientation with respect to each other (and thus the positioning of substrate and cofactor) are less efficient in the hybrid, although preliminary modeling studies indicated that these interactions are considerably conserved in C.clifficile and P.furiosiss GDH.

The C.difficile-P.furiosus hybrid GDH shows a thermoactivity that is only slightly higher than that of the mesophilic parental enzyme. Apparently, the presence of a domain from a hyperthermostable enzyme does not significantly enhance the temperature at which the enzyme becomes susceptibie towards thermal inactivation during catalysis, and thermoactivity might be determined by the weakest or more flexible part of the protein. It may be envisaged that the mesophilic domain reaches its maximum liexibility at the temperature optimum and starts unfolding, while the thermostable domain 
is still too rigid to be able to bind and release substrates efficiently, explaining the low catalytic efficiency of the hybrid. Although the thermoactivity of the hybrid is relatively low, it is more stable towards chemical denaturation than its mesophilic parental enzyme, most likely because of the presence of the P.furiosus glutamate binding domain. The apparent two-state cooperative transition profile, obtained by fluorescence emission and ellipticity measurements of $\mathrm{GdmCl}$-denatured hybrid GDH, is the same as for C.difficile GDH. Although kinetic parameters suggest that both domains are structurally independent and may be able to fold independently, the hybrid unfolds without any detectable preliminary loss of secondary structure of the C.difficile colactor binding domain.

The effect of domain exchange on thermostability is dramatic. Instead of obtaining a hybrid displaying a thermostability in between those of the parental enzymes, as found in the case of chemical stability, the hybrid is even less thermostable than C.difficile GDH. Enzymes from (hyper)thermophilic organisms are usually characterized by a high stability towards physical and chemical denaturation (Fontana, 1991). In the case of the hybrid, the increased stability towards GdmCl with respect to C.difficile $\mathrm{GDH}$ is not accompanied by a corresponding increase in thermostability. It should be noted that clomain I of the hybrid does not consist completely of P:furiosus residues; the $\mathrm{C}$-terminal $\alpha$-helix 17 (numbering as in C..symbiosum GDH; Baker et al., 1992) crosses over from domain II and is composed of C.difficile residues. Preliminary modeling studies indicate that the efficient packing of this $\alpha$-helix against the P.furiosus domain is impaired because the possibility of forming hydrogen bridges is reduced and several residues will cause steric hindrance. The importance of a C-terminal $\alpha$-helix for thermostability has been shown previously with the glyceraldehyde-3-phosphate dehydrogenase because its removal led to a dramatic decrease in the thermostability of the M.fervidus enzyme (Biro et al., 1990). Furthermore, the packing of this C-terminal helix in GDH may also have effects on thermoactivity and catalytic efficiency because it is involved in orientating the two domains with respect to each other. The construction of hybrid GDHs with an additional exchange of this $\alpha$-helix is in progress to allow us to study the possibility of obtaining more efficient and thermostable enzymes.

In conclusion, we have demonstrated that it is possible to successfully exchange parts of homologous proteins from micro-organisms that are phylogenetically very distant and belong to the archaea and bacteria. Furthermore, it has been shown that thermoactivity and thermostability are not necessarily linked to chemical stability and may be engineered independently, offering the possibility of constructing enzymes that are optimally active at low temperatures while retaining an extreme chemical stability.

\section{Acknowledgements}

We are grateful to Professor David Rice, Linda K.Britton and Timothy J.Stillman for their help with the protein modeling. This work was partially supported by contract BIOT-CT93-0274 of the European Union.

\section{References}

Baker,P.J., Britton,K.L., Engel,P.C., Farrants,G.W., Lilley,K,S., Rice,D.W. and Stillman,T.J. (1992) Proteins: Struct. Funct. Genet., 12, 75-86.

Benachenhou-Lahfa,N., Forterre,P. and Labedan,B. (1993) J. Mol. Evol., 36, 335-346.

Bernard,H.U., Remaut,E., Hershfield,M.V., Das,H.K., Helmshi,D.D.,
Yanofisky,C. and Franklin,N. (1979) Genc, 5, 59-76.

Biro,J., Fabry,S., Dietmaier,W., Bodegain,C. and Hensel,R. (1990) FEBS Letl., $275,13()-134$.

Chan,M.K., Mukund,S., Kletzin,A., Adlams,M.W.W. and Rees,D.C. (1995) Science, 267, 1463-1469.

Consalvi, V., Chiaraluce, R., Politi,L., Vacearo, R., de Rosa,M. and Scandurra,R. (1991) Eur: J. Biochem., 202, 1189-1196.

Day,M.W., Hsu,B.T., Joshua-Tor,L., Park,J., Zhou,Z.H., Adams,M.W.W. and Rees,D.C. (1992) Protein Sci., 1, 1494-1507.

Diruggiero,J. and Robb,F.T. (1995). Appl. Environ. Microbiol., 61, 159-164. Eggen,R.J.L., Geerling,A.C.M, Waldkötter,K., Antranikian,G. and de Vos,W.M. (1993) Gene, 132, 143-148.

Eggen,R.I.L., Geerling,A.C.M., Voorhorst,W.G.B., Kort,R, and de Vos,W.M. (1994) Biocatalysis, 11, 131-141.

Fontana,A. (1991) In de Presco,G. (ed.), Life under Extreme Conditions: Biochemical Adaptation. Springer-Verlag, Berlin, Germany, pp. 89-113.

Gibson,T.J. (1984) PhD thesis, Cambridge University, Cambriclge, UK.

Gill,S.C. and von Hippel,P.H. (1989) Anal. Biochem., 182, 319--326.

Goldenberg,D.D. (1992) In Creighton,T.E. (ed,), Protein Folding. W.H. Freeman and $C_{0 .}$, NY, pp. 353-403.

Jaenicke,R. (1991) Eur: J. Biochem., 202, 715-m728.

Jecht,M., Tomschy,A., Kirscher,K, and Jaenicke,R. (1994) Protein Sci., 3, $411-418$.

Kataoka,K., Takada,H., Tanizawa,K., Yoshimura,T., Esaki,N., Ohsima,T, and Soda,K. (1994) J. Biochem., 116, 931-.936.

Kengen,S.W.M. and Stams,A.J.M. (1994) Arch. Microbiol., 161, 108-175.

Korndörfer,I., Steipe,B., Huber,R., Tomschy,A. and Jaenicke, R. (1995) .J. Mol. Biol., 246, 511-521.

Leatherbarrow,R.I, (1987) ENZFTTTER. Elsevier-Biosoft, Cambridge, UK.

Lyerly,D.M., Barosso,L.A. and Wilkins,T.D. (1991) J. Clin. Microbiol., 29, 26.39.-2642.

Maras,B., Valiante,S., Chiaraluce,R., Consalvi,V., Politi,L., de Rosil,M., Bossal,F, Scandurra, R. and Barra,D. (1904) J. Protein Chem., 13, 253-25\%.

Onodera,K,, Sakurai,M., Moriyama,H., Tanaka,N., Numata,K., Ohshima,'T., Sato,M. and Katsube,Y. (1994) Protcin Engng, 7, 453-459.

Pace,C.N. (1986) Mothods Enzymol., 131, 266-280).

Remilut,E., Stanssens,P. and Fiers, W. (1981) Gone, 15, 81 -.9.3.

Sambrook,J., Fritsch,E.F. and Maniatis,T, (1989) Molectular Cloning: A Laboratory Mamual, 2nd edn. Cold Spring Harbor Laboratory Press, Cold Spring Harbor, NY.

Sanger,F., Nicklen,S, and Coulson,A.R. (1977) Proce Natl Acacl. S'si. LISA, $74,546,3-5467$.

Segel,I.H. (1975) Enzrme Kinetics. Wiley, New York, pp. 844-m944.

Smith,E.L., Austen,B.M., Blumenthal,K.M. and Nyc,J,I\%, (1975) In Boyer, P.D. (ed.), The Enzymes. Academic Press, New York, Vol, XI, pp. 293-367.3.

Stetter,K.O., Fiali,G., Huber,G., Huber,R, and Segerer,A. (199()) FEMS Microbiol. Re'v, 75, 117-124.

Stillman,T.I., Baker,P.J., Britton,K.L. and Rice,D.W. (l9).3) J. Mol. Biol., 234, 11.31-1139.

Tomic,M., Sunjevaric,I., Savtchenko,E.S. and Blumenberg, M. (199)) Nucleic Acids Res., 18, 1656.

Tomschy,A., Böhm,G, and Jaenicke, R. (1994) Protcin Eingng, 7, 1471-1478. Yannisch-Perron,C., Viera,J. and Messing,J. (1985) G('nc, 33, 10,3-119.

Received July 13, 1995; revised September 29, 1995; acecepted Octoher 0, 1995 